\title{
Factors Affecting Liquidity Risk in the System of Vietnamese Commercial Banks
}

\author{
TRUOONG QUANG THÔNG \\ University of Economics HCMC \\ truongquangthong@yahoo.com
}

\begin{tabular}{|c|c|}
\hline ARTICLE INFO & ABSTRACT \\
\hline $\begin{array}{l}\text { Article history: } \\
\text { Received: } \\
\text { July 09, } 2013 \\
\text { Received in revised form } \\
\text { Aug. 06, } 2013 \\
\text { Accepted: } \\
\text { Dec. } 31,2013 \\
\end{array}$ & $\begin{array}{l}\text { The research tries to identify causes of liquidity risk for the system of } \\
\text { Vietnamese commercial banks. Data for the research are collected } \\
\text { from annual reports in the years } 2002-2011 \text { by } 27 \text { Vietnamese } \\
\text { commercial banks. The liquidity risk examined in the research is } \\
\text { financing gap; and independent variables, or factors affecting the } \\
\text { liquidity risk, are divided into two groups: internal and external ones. } \\
\text { The estimated results of the models show that the liquidity risk among } \\
\text { banks depends not only on internal factors, such as total asset size, } \\
\text { liquidity reserve, inter-bank loan, and ratio of equity to capital, but } \\
\text { also on external ones, or macroeconomic factors, such as growth rate, } \\
\text { inflation, and especially effects of policy lags. }\end{array}$ \\
\hline
\end{tabular}




\section{INTRODUCTION}

There are numerous debates about the liquidity problems of Vietnamese banking system. Some suggest that the main cause is an overall small scale, whereas others maintain that liquidity supply of such a developing economy as that of $\mathrm{VN}$ is comparatively limited. Several authors also argue that the liquidity problem is greatly influenced by fiscal and monetary policies adopted by the Government.

The research aims to identify the causes of liquidity risk for the system of Vietnamese commercial banks. According to the model, one dependent variable is "financing gap" measured by the difference between bank loans and deposits divided by total assets while independent variables are categorized into two groups: (i) internal factors include total asset size, average asset size, ratio of liquidity reserve to total asset, dependency on external sources of finance, and ratio of equity capital to total capital, etc.; and (ii) external factors are macroeconomic factors, such as GDP growth, changes in money supply, and changes in inflation rate. In addition, to estimate the effects of policy lags, such variables as $\mathrm{GDP}_{\mathrm{t}-1}, \mathrm{M}_{\mathrm{t}-1}$ and $\mathrm{INF}_{\mathrm{t}-1}$, corresponding to GDP growth, change in money supply, and change in inflation rate in the previous year are included in the model. The two regression models employed in the study are fixed and random effects.

Estimated results indicate that bank liquidity risk depends not only on factors within the banking system such as total asset, liquidity reserve, inter-bank loan, and the ratio of equity capital to total capital but also on macroeconomic variables such as economic growth and inflation, especially expressed through the impact of policy lags. In particular, the variable of total assets generates nonlinear effects on liquidity risk, which means that an increase, in the initial stage, in assets would bring about liquidity risk reduction. Yet, the risks would increase if the assets increase to a certain extent. Another concern is that a higher growth rate in the current year would result in risk mitigation in the same year but increase the liquidity risk in the next year. Similarly, the inflation index does not affect liquidity risk in the same year but reduces them later.

The results from the analysis have yielded important policy implications. The massive increase in bank capital as required by Decree 141/2006/NĐ-CP has created unexpected impacts. Liquidity surplus and, subsequently, continuous liquidity deficit require that specifics and/or particular circumstances of specific bank (groups) be taken into account when demanding increases in chartered capital or total asset. 
Another implication from the findings is the role of the government and the SBV in the establishment and strict implementation of economic development policies and inflation control measures, thus providing public inspiration. The SBV should truly be a reliable management and monitoring agency, particularly in terms of the policies or economic solutions. Once it successfully proves its consistency in the implementation of its target inflation policy announced, the market confidence is strengthened, and as a result, unexpected impacts through the latency of inflation could then be controlled within the limits of the target policy.

To the authors' best knowledge, the study is the first in Vietnam that aims to discover the factors, both internal and external ones, affecting liquidity risk of Vietnamese banking system with large panel data. However, due to constraints of time and finance, the study has yet to examine such other indexes as Official Supervisory Power Index (OSP), Private Monitoring Index (PMI), and the likes to measure the impact of institutions and banking supervision monitored by governmental agencies, which is considered one of the drawbacks currently recorded. Any improvement, therefore, would be on the development of the dataset including more observed variables and the extension of similar researches on liquidity and efficiency of the banking system or specific factors affecting bank liquidity creation.

\section{LIQUIDITY RISK AND METHODS OF MEASUREMENT}

According to the Basel Committee on Banking Supervision (1997), liquidity risk stems from the bank's inability to increase capital items to support an increase in bank assets. In the perspective of liquidity management, any kind of surplus or shortage describes the imbalance of the bank. Liquidity surplus occurs either when the economy operates ineffectively, resulting in a lack of investment and business opportunities or when a bank shows incompetence in its access to markets and customers. The other causes of surplus may also be insufficient exploitation of the productive assets or excessive growth in capital compared with the scale of operation and management capability. In contrast, liquidity shortage refers to inadequate capital for operation, which should cause more serious problems to the existence and development of the bank, namely losses in business opportunities, customers, markets, and a decline in public trust (Trương, 2012).

Liquidity risk can be measured in two aspects: financing gap and liquidity coefficients. According to Vodová (2013), financing gap is the difference between assets 
and capital for both the present time and the future. Liquidity coefficients are different coefficients calculated from the bank balance sheet and often used to predict trend movements of liquidity.

Compared to other risks in the banking business such as credit risk and interest rate risk, etc., liquidity risk may be a subject rarely discussed in academic researches. Poorman \& Blake (2005) pointed out that only using liquidity coefficients to measure liquidity risk is barely adequate. In an overall view, theories and researches take little notice of analyzing the causes of liquidity risk, especially external ones beyond control of a bank, such as macroeconomic factors, institutional factors and supervision. Saunders \& Cornett (2006) suggested using the term "financing gap" to measure liquidity risk.

Bank liquidity controllers are often interested in the two items in the balance sheet average balance of core deposits and average balance of credits. In banking business, the majority of assets will be financed by deposits, most of which are from current accounts and can be withdrawn from the bank at any time, thus creating a financing gap and subsequently liquidity risk (Arif \& Anees, 2012). Ordinary loans have a low liquidity, so substantial, unpredictable and large withdrawals may lead to the loss of bank liquidity (Bonin et al., 2008).

Since financing gap is the difference between the average of the loans and the average of core deposits, it could be the theoretical basis to be employed as a dependent variable in the research model proposed in the next section. Independent variables or factors affecting liquidity risk can be divided into two groups: bank-specific performance factors and external factors, such as macroeconomic ones (Decker, 2000).

In another empirical study, Chung-Hua (2009) applied a model on causes of liquidity risk to commercial banking systems of 12 leading economies over the period 1994-2006. Through such model, internal variables used to measure causes of liquidity risk include total asset size, ratio of liquidity reserve to total assets, dependency on external funding, ratio of equity to total capital, ratio of total loans to total assets, and ratio of credit risk provisions to total loans. External independent variables include macroeconomic ones such as economic growth and inflation rates. Other studies by Vodová (2011, 2013a, 2013b) used such extra variables as inter-bank interest rate, repo rate, and unemployment rate. 


\section{DATA AND RESEARCH METHODOLOGY}

\section{a. Data:}

Data used to test the model featuring unbalanced panel data were initially collected from financial statements of 34 Vietnamese commercial banks in the period 2002-2011. Adequate data within a period of 6 years or more were gathered for the case of 27 banks out of the original 34 banks, which means the remaining 7 banks were not qualified. The results from the study should be consequently applied to the qualified 27 banks and there would be 212 observations in total. Data about macroeconomic variables were gathered from IMF sources.

\section{b. Research Methodology:}

Quantitative method with the regression model used for the research is as follows:

$$
\begin{aligned}
\mathrm{FGAP}_{\mathrm{it}}=c_{i}+ & \lambda_{1} S I Z E_{i t}+\lambda_{2} S I Z E_{i t}^{2}+\lambda_{3} L R A_{i t}+\lambda_{4} E T A_{i t}+\lambda_{5} E F D_{i t} \\
& +\lambda_{6} T L A_{i t}+\lambda_{7} L L P T L_{i t}+\delta_{1} G D P_{t}+\delta_{2} M 2_{t}+\delta_{3} I N T_{t}+\delta_{4} G D P_{t-1} \\
& +\delta_{5} M 2_{t-1}+\delta_{6} I N T_{t-1}+\varepsilon_{i t}
\end{aligned}
$$

According to the model, apart from FGAP, a dependent variable, measured by the difference between bank loans and deposits divided by total assets, independent variables are categorized into two groups:

- Internal independent variables

+ Total asset size (SIZE):

Regarding total asset size, natural logarithm is employed to measure bank size. Additionally, the variable of square total assets $\left(\mathrm{SIZE}^{2}\right)$ is also included in the model along with an assumption of non-linear relationship of total assets and liquid assets held, and subsequently liquidity risk (Dinger, 2009). Theoretically, a bank with a greater total asset would face less liquidity risk. Large banks may rely on the inter-bank market or liquidity support from the lender of last resort (Vodová, 2013b). However, "too big to fail" perspective, so recent arguments run, suggests that large banks, due to benefiting greatly from implicit assurance and dubious advantages, can possibly reduce costs of mobilizing capital, which allows them to make more investments in riskier assets, such as loans. As a result, larger banks have the ability to invest more in loans and thereby increasing financing gaps. The relationship between assets and liquidity risk (financing gap) is accordingly expected to be non-linear.

+ Ratio of liquidity reserve to total assets (LRA) 
Liquidity reserve may fall into two categories: primary and secondary reserve, which is a traditional liquidity control of commercial banks (Trương, 2012). As a matter a fact, banks drawing on higher reserve may face less liquidity deficit. Asset sales or mortgages give rise to liquid capital; therefore, certain liquidity reserve would reduce the risk (Chung-Hua, 2009), and a negative relationship between these two is also expected.

+ External funding dependence (EFD)

Another variable is external funding dependence that is calculated by total capital divided by total inter-bank loans. This is a liquidity management strategy based on bank's capital in which loans from inter-bank market are used for covering liquidity needs. However, it would encounter very high degrees of liquidity risk (Vodová, 2013a), particularly when the bank has to ask for a loan from inter-bank market even with an absolutely high interest rate during liquidity crises. Moreover, if banks use such loans to meet depositors' withdrawals, it may increase the debt-to-equity ratio, thus affecting efforts to maintain optimal capital structure of the bank (Arif \& Anees, 2012). Since external funding consequently increases liquidity risk. The two factors are expected to have a positive relationship.

+ Ratio of equity to total asset (ETA)

This may be considered a substitute for capital adequacy ratio (CAR) suggested by Basel in the framework of capital adequacy regulations (Vodová, 2013a). Equity itself is a cushion, a final shield to fend off various banking risks (Trương, 2012). Hence, there shall be an expectation of a negative relationship between ETA and liquidity risk.

+ Ratio of total loans to total assets (LTA)

In Vietnamese banking system, or those of emerging economies, banks usually turn the best part of funds into loans. These typically feature low liquidity and unpredictable and large withdrawals can lead to the loss of bank liquidity (Bonin et al., 2008). A positive relationship between LTA and liquidity risk is expected.

+ Ratio of loan loss provision to total loans (LLPTL)

Expenditure on loan loss provisions is also used to test the impact of liquidity risk, representing the credit risk level of banks (Chung-Hua, 2009). Credit risk in turn will impact on profitability and liquidity risk. The higher the cost spent on loan loss provisions, the higher liquidity risk becomes. Thus, they are expected to have a positive relationship. 
- External independent variables:

+ Economic growth:

Theoretically, banks would hold more liquidity in periods of economic recession as lending service is increasingly risky, and conversely, during period of high economic growth, they tend to reduce liquidity reserve to offer more loans while bank deposits may decrease, which makes financing gap expands, thus entailing liquidity risk (ChungHua, 2009). Dinger (2009) argues that liquidity reserve is negatively related to economic growth. In the model, a positive relationship between economic growth and liquidity risk is also expected.

+ Inflation rate changes

The relationship between inflation and liquidity risk still causes heated debates. Perry (1992) pointed out the relationship between liquidity and bank performance depends on the level of inflation expectation. If the inflation is fully expected, banks may adjust interest rates to make their interest income increase faster than interest cost. Banks can increase bank loans, but bank deposits may be curtailed due to competition, which increases financing gap and subsequently liquidity risk. Vodová (2011, 2013a, 2013b) showed that the impacts of inflation change are positive related to liquidity risk. Thus, a positive relationship between inflation and liquidity risk is expected.

$+\mathrm{M} 2$ changes

According to Friedman (1963), money supply should keep pace with economic growth; thus, an excessive supply will be the root of inflation. Change in money supply through various instruments employed by the central bank can influence the liquidity of commercial banks, or in other words, a loose monetary policy may increase liquidity. Theoretical bases allow the author to expect a negative relationship between M2 changes and liquidity risk.

To estimate the impact of macroeconomic policy lags, such variables as $\mathrm{GDP}_{\mathrm{t}-1}, \mathrm{M} 2_{\mathrm{t}-1}$ and $\mathrm{INF}_{\mathrm{t}-1}$, which are GDP growth, M2 change, and inflation rate change of the previous year respectively, in addition, shall be included in the model.

\section{ANALYSIS AND RESULT DISCUSSION}

\section{a. Results of Descriptive Statistics:}

Results of descriptive statistics, measured by quantities typical of the variables, are illustrated in Table 1. 
Table 1: Results of Descriptive Statistics (\%, VND billion)

\begin{tabular}{lcccccc}
\hline Variable & Mean & Median & Max & Min & Standard Deviation & Obs. \\
\hline FGAP & 0.047 & 0.253 & 91.939 & -53.537 & 21.200 & 212 \\
EFD & 26.345 & 22.306 & 97.287 & 0.000 & 18.359 & 212 \\
ETA & 12.426 & 9.663 & 71.206 & 2.342 & 9.794 & 212 \\
TLA & 63.184 & 65.513 & 99.530 & 1.003 & 18.364 & 212 \\
SIZE & $64,096.149$ & $18,930.862$ & $535,000.000$ & 144.861 & $98,868.613$ & 212 \\
LRA & 31.746 & 29.437 & 96.038 & 3.779 & 16.178 & 212 \\
LLPTL & 0.765 & 0.475 & 3.656 & 0.016 & 0.759 & 212 \\
\hline GDP & 7.16 & 7.21 & 8.46 & 5.32 & 1.09 & 10 \\
GDP & 7.27 & 7.21 & 8.46 & 5.32 & 1.01 & 10 \\
INF & 10.08 & 8.95 & 19.89 & 3.00 & 5.70 & 10 \\
INF ${ }_{\mathrm{t}-1}$ & 8.31 & 7.50 & 19.89 & 0.80 & 5.53 & 10 \\
M2 $_{\text {M2 }}$ & 30.300 & 29.600 & 46.100 & 17.600 & 8.422 & 10 \\
\hline
\end{tabular}

Source: Author's calculations

Liquidity risk (FGAP - ratio of financing gap to total asset): The mean of the 27 banks is $0.047 \%$; max and min are $32.14 \%$ and $33.10 \%$ respectively. Liquidity risk is recorded primarily with 15 medium- and small-sized banks.

External funding dependence (EFD): The ratio of interbank loans and other loans to total capital of 27 Vietnamese banks is relatively high, 26.35\% on average and 54.24\% as the highest. High EFD is found mainly in small-sized banks.

Ratio of equity to total assets (ETA): the overall mean of this variable is $12.426 \%$, along the max of $30.19 \%$ and min of $3.96 \%$. For small banks this figure is always higher than that of the large ones.

Ratio of total loans to total assets (TLA): Vietnamese banks show very high ratios with the average of $63.184 \%$, the max of $87.00 \%$ and the $\min$ of $38.65 \%$.

Total asset size (SIZE): Results from the analysis show an average of total asset size of a bank is VND64,096 billion.

Ratio of liquidity reserve to total asset (LRA): This ratio is pretty high with the average, max and $\min$ of $31.75 \%, 53.47 \%$ and $12.53 \%$ respectively. 
Ratio of loan loss provisions to total loans (LLPTL): The results reveal low ratios with an average of $0.765 \%$.

External factors (GDP, INF, M2): In the period 2002-2011, average growth rate, inflation rate and change in money supply in Vietnam were $7.16 \%, 10.08 \%$ and $30.3 \%$ respectively.

\section{b. Results of Regression Analysis:}

To examine how internal and external factors influence liquidity risk, three approaches to model estimation were adopted, including model combining all observations (Pooled), fixed effects model (FEM) and random effects model (REM), also known as error component model (ECM). Analyses of R2, Durbin-Watson statistics, Hausman test, and correlation between ei error and independent variables could help us select an appropriate model.

- Differences among Pooled, FEM and REM:

Pooled ignores pooled data size over space and time and only estimates the traditional OLS regression model.

FEM: Assuming that each entity has its own unique characteristics affecting explanatory variables, FEM performs an analysis of the correlation between the residuals of each entity and the explanatory variables and thereby establishing control and separating the influence of individual characteristics (constant over time) from the explanatory variables to estimate the real effect of explanatory variables on dependent ones.

REM: Random effects approach indicates that the difference in specific conditions of cross units contained in random error. Specific characteristics between entities are assumed to be random and not correlate with the explanatory variables.

Estimation results are reflected in Table 2 and 3.

Table 2: Estimation of the Model with Internal Factors

\begin{tabular}{lc|ccc|cc}
\hline Estimation & Pooled & \multicolumn{3}{c|}{ FEM } & \multicolumn{2}{c}{ REM } \\
\hline \multicolumn{1}{c}{ Model } & $\mathbf{1}$ & $\mathbf{1}$ & $\mathbf{2}$ & $\mathbf{3}$ & $\mathbf{1}$ & $\mathbf{2}$ \\
\hline $\mathrm{C}$ & $0.860^{* * *}$ & $1.467 * * *$ & $1.788^{* * *}$ & $1.152 * * *$ & $0.860 * * *$ & $0.979 * * *$ \\
EFD & $0.783^{* * *}$ & $0.766 * * *$ & $0.783 * * *$ & $0.802 * * *$ & $0.783 * * *$ & $0.787 * * *$ \\
ETA & $0.818^{* * *}$ & $0.818^{* * *}$ & $0.810^{* * *}$ & $0.823 * * *$ & $0.818 * * *$ & $0.809 * * *$
\end{tabular}




\begin{tabular}{lc|ccc|cc} 
LLPTL & $-1.098^{* * *}$ & $0.003 * * *$ & $-0.350^{* * *}$ & $-1.616^{* * *}$ & $-1.098 * *$ & $-1.169 * * *$ \\
LRA & $-0.745^{* * *}$ & $-0.672 * * *$ & $-0.634 * * *$ & $-0.712^{* * *}$ & $-0.745^{* * *}$ & $-0.735^{* * *}$ \\
TLA & $0.474 * * *$ & $0.429 * * *$ & $0.487 * * *$ & $0.520 * * *$ & $0.474 * * *$ & $0.487 * * *$ \\
SIZE & $-0.154 * *$ & $-0.221 * * *$ & $-0.248 * * *$ & $-0.195 * * *$ & $-0.154 * * *$ & $-0.169 * * *$ \\
SIZE ${ }^{2}$ & $0.005^{* *}$ & $0.007 * * *$ & $0.007 * * *$ & $0.006 * * *$ & $0.005 * * *$ & $0.005 * * *$ \\
\hline Cross-section & None & Fix & Fix & none & Random & none \\
Period & None & none & Fix & Fix & none & Random \\
\hline Obs. & 212 & 212 & 212 & 212 & 212 & 212 \\
R & 0.8339 & 0.8504 & 0.8608 & 0.8417 & 0.8339 & 0.8363 \\
DW & 1.33 & 1.67 & 1.72 & 1.38 & 1.33 & 1.34 \\
\hline
\end{tabular}

Source: Author's calculations

Estimation results illustrated in Table 2 indicate that in all models, excluding FEM_3, except for LLPTL, the other factors EFD, ETA, LRA, TLA, SIZE generally have influence on liquidity risk. Particularly, EFD, ETA and TLA exert positive impacts on the liquidity risk whereas LRA has a negative impact. As with the results, there exists a negative statistical significance in the relationship between SIZE and FGAP but a positive one in that between FGAP and SIZE2, which suggests that total asset size and liquidity risk reveal a non-linear relationship; an increase of SIZE would reduce the risk at first but would increase it under certain conditions of continuity.

Table 3: Estimation of the Model with Both Internal and External Factors

\begin{tabular}{lccc}
\hline \multicolumn{1}{c}{ Estimation } & Pooled & FEM & REM \\
\hline C & $1.483 * * *$ & $2.034 * * *$ & $1.595 * * *$ \\
EFD & $0.798^{* * * *}$ & $0.790^{* * *}$ & $0.795^{* * *}$ \\
ETA & $0.799 * * *$ & $0.793 * * *$ & $0.795 * * *$ \\
LLPTL & $-1.272 * * *$ & $-0.114 * * *$ & $-1.072 * * *$ \\
LRA & $-0.716^{* * *}$ & $-0.642 * * *$ & $-0.708^{* * *}$ \\
TLA & $0.508^{* * * *}$ & $0.475 * * *$ & $0.505 * * *$ \\
SIZE & $-0.204 * * *$ & $-0.233 * * *$ & $-0.216^{* * *}$
\end{tabular}




\begin{tabular}{lccc}
$(\mathrm{SIZE})^{2}$ & $0.006^{* * *}$ & $0.006^{* * *}$ & $0.007 * * *$ \\
$\mathrm{GDP}$ & $-0.052^{* * *}$ & $-0.067 * * *$ & $-0.053^{* * *}$ \\
$\mathrm{GDP}_{\mathrm{t}-1}$ & $0.021^{* * *}$ & $0.004^{* * *}$ & $0.021^{* * *}$ \\
$\mathrm{INF}$ & $-0.005^{* * *}$ & $-0.008^{* * *}$ & $-0.005^{* * *}$ \\
$\mathrm{INF} \mathrm{t}_{-1}$ & $-0.006^{* * *}$ & $-0.005^{* * *}$ & $-0.006^{* * *}$ \\
$\mathrm{M} 2$ & $-0.001^{* * *}$ & $0.003^{* * *}$ & $0.001 * * *$ \\
$\mathrm{M} 2_{\mathrm{t}-1}$ & $0.003^{* * *}$ & $0.006^{* * *}$ & $0.003 * * *$ \\
\hline $\mathrm{Cross}-\mathrm{section}$ & none & Fix & Random \\
Period & none & none & None \\
\hline Obs & 212 & 212 & 212 \\
$\mathrm{R}^{2}$ & 0.8416 & 0.8621 & 0.8298 \\
$\mathrm{DW}$ & 1.38 & 1.71 & 1.42 \\
\hline
\end{tabular}

Source: Author's calculations

If external factors GDP, INF, and M2 with lagged values are included in the model, the results presented in Table 3 show that EFD, ETA and TLA have positive correlations with FGAP; LRA has a negative correlation with FGAP, whereas SIZE has a non-linear correlation with FGAP. LLPTL itself is not statistically significant in relation to FGAP in all of the three estimation models.

Concerning external factors, the results also point out that both GDP and GDPt-1 affect liquidity risk, but still the former goes with a negative statistical significance, and the latter, positive significance. This reflects higher economic growth in the current year would reduce liquidity risk but that over the previous year would increase it.

Remarkably, GDPt-1 has an overall effect on the entire banking system over time (Pooled model of Table 3) but not a separate one on individual banks (FEM model). In addition, analysis results also show that a higher inflation rate of the previous year mitigates liquidity risk of the current year.

\section{- Wald test for selecting Pooled or FEM model:}

OLS regression shows signs of autocorrelation, causing the testing values to be incorrect while Wald test yields the $\mathrm{F}$ value of the two models (one without external factors and the other with) being 72.33752 and 41.65765 respectively with $\mathrm{P}$-value $=$ 
$0,000<\alpha=5 \%$, resulting in the rejection of hypothesis H0. Thus, FEM is the better choice for both estimation models, with and without external factors.

\section{Hausman test for selecting FEM or REM}

Prior to an adoption of FEM and REM, a Hausman test has been conducted to decide whether FEM and REM differ from each other in the research sample.

\section{Table 4: Results of Hausman Test}

Absence of external factors

Correlated Random Effects - Hausman Test

Equation: REM

Test cross-section random effects

Test Summary

Chi-Sq. Statistic

Chi-Sq. d.f.

Prob.

Cross-section random

29.77

7

0.0001

Period random

11.73

7

0.1099

Existence of external factors

Cross-section random

0.00

13

1.000

Source: Author's calculations

The results in Table 4 suggest that Cross-section estimation using FEM, when estimated without external factors, is more suitable than REM (p-value $=0,0001<$ $\alpha=5 \%$ ) while results for Period are not remarkably different ( $p$-value $=0,1099>\alpha=5 \%$ ).

With external factors included, results of REM and FEM estimation are not remarkably different ( $\mathrm{p}$-value $=1>\alpha=5 \%$ ).

Due to a large number of cross units $(\mathrm{N})$ which are not randomly selected and a limited number of time series, FEM is preferable.

\section{c. Result Discussions:}

The testing results lead to the following important remarks.

- Concerning internal factors:

Total assets of enterprises have non-linear effects on bank liquidity risk; an asset increase in the initial stage reduces liquidity risk yet increases it if the asset increase 
reaches a certain extent. Deléchat et al. (2012) also have similar findings: the coefficients of liquidity risk have non-linear correlation with bank size but there will be a threshold over which an increase in bank size exerts a marginal impact that incurs the risk.

This result is quite compliant with another 'paradoxical' one in the model: An increase of $1 \%$ in the ratio of equity to total assets increases liquidity risk by $0.793 \%$, whereas the results offered by Vodová (2013) shows the consistence with the theoretical background: equity has a negative relationship with liquidity risk.

Liquidity risk itself is strongly affected by the three factors: EFD, ETA and LRA. A $1 \%$ increase in the ratio of liquidity reserve to total asset would help reduce liquidity risk by $0.642 \%$. On the other hand, a $1 \%$ decrease in the ratio of bank loans and other loans to total asset would reduce liquidity risk by $0.790 \%$.

- Concerning external economic environment:

The results indicate that a higher speed of economic growth (GDP) in the current year mitigates liquidity risk of the same year but will increase that in the following year. In addition, changes in inflation rate do not affect liquidity risk in the current year but do reduce it in later years.

Loan loss provisions and $\mathrm{M} 2$ increase are found in the research not to have an effect on liquidity risk in the system of Vietnamese commercial banks.

\section{CONCLUSIONS AND POLICY IMPLICATIONS}

- Concerning the policies on increases in bank capital and asset, as well as management of bank asset and capital in the past time:

Requirements of chartered capital increase posed by Decree 141/2006/NĐ-CP along with favorable conditions offered by the stock market in the period 2006-2007 provided small-sized banks in Vietnam a rare opportunity for development. After six years (up to 2012), however, the banks remained unchanged in size and most of the cases have been recorded with limited financial strength and liquidity shortage, as well as lack of competency and experiences in management of larger and riskier banks.

Obviously, increasing capital and subsequently increasing assets proved to be a solution beyond the reach of these small banks. Such a matter with the Vietnamese banking system reveals the most striking example of bank management policies seemingly deemed a universal remedy for all problems. Liquidity surplus and consecutive liquidity deficit require that policies on chartered capital and asset increase 
on both macro and micro levels should take into account specifics and individual situations of the specific banks and groups of banks. The increase in assets must also be associated with reasonable and safe allocation and use of assets, and full attention should be paid to portfolio of liquidity reserve assets to ensure a safety net for liquidity. After all, banks should maintain a rational capital structure by increasing the proportion of deposits from individual and organizations while avoiding a capital structure heavily dependent on loans from inter-bank market.

- On Vietnam's economic growth, inflation, inflation expectation and policy of target inflation:

The Vietnamese economy has already paid pretty steep price in a vicious circle amidst economic growth, inflation and consequently liquidity crisis. The faith of investors in economic growth over the previous periods (before 2007) stimulated more investments and loans, which caused liquidity risk for the following years as affected by policy lags. Expectations of economic growth allowed the investment and bank loan to increase faster than bank deposit, which is coupled with the negative impacts of inflation to widen the financing gap. In the long period before 2007, the money supply was increased strongly to support economic growth. In 2008, the tight monetary policy was adopted and was replaced by a loose one in 2009 , making inflation relapse.

The test results of the models demonstrate a theoretical problem: The level of inflation expectations of the public depends on the past inflation rates. Evidently, high and continuous inflation in $\mathrm{VN}$ from 2008 up to now has had a strong impact on inflation expectations of the public and thereby requiring the Government and SBV to make and implement economic policies carefully and consistently to enhance public confidence. The central bank should genuinely be a reliable management and monitoring agency, especially through the signals and messages about economic policies or solutions. No sooner has the consistency in the implementation of target inflation policy been proved than the market's confidence can be strengthened and the unexpected effects of inflation lags can be controlled within the limits of target policies

\section{References}

Arif, A. \& A. Anees (2012), "Liquidity Risk and Performance of Banking System”, Journal of Financial Regulation and Compliance, Vol.20(2), pp.182-195. 
Basel Committee on Banking Supervision (1997), Core Principles for Effective Banking Supervision, Bank for International Settlements.

Bonin, J., H. Iftekhar \& P. Wachtel (2008), Banking in Transition Countries, BOFIT Discussion Paper, the Oxford Handbook of Banking.

Chung-Hua Shen, Yi-Kai Chen, Lan-Feng Kao \& Chuan-Yi Yeh (2009), Bank Liquidity Risk and Performance, Department of Finance, National Taiwan University.

Decker, P.A. (2000), The Changing Character of Liquidity Risk Management: A Regulator's Perspective, Federal Reserve Bank of Chicago Banking Supervision and Regulation Research.

Deléchat, C. et al. (2012), "The Determinants of Banks' Liquidity Buffers in Central America”, IMF Working Paper No. 12/30.

Dinger, V. (2009), “Do Foreign-Owned Banks Affect Banking System Liquidity Risk?”, Journal of Comparative Economics, Vol.37(4), pp.647-657.

Friedman, M. (1963), Inflation: Causes and Consequences, Proquest Info and Learning.

Nishiyama, Shin-Ichi (2003), Inflation Target as a Buffer Against Liquidity Trap, Bank of Japan, Discussion Paper No 2003-E-8.

Perry, P. (1992), “Do Banks Gain or Lose from Inflations?”, Journal of Retails Banking, Vol.14, pp.25-30.

Poorman Jr., F. \& J. Blake (2005), Measuring and Modeling Liquidity Risk: New Ideas and Metrics, Financial Managers Society Inc., white paper.

Saunders, A. \& M.M. Cornett (2006), Financial Institutions Management: A Risk Management Approach, Mc Graw-Hill, Boston.

Trương Quang Thông (2012), Quản trị ngân hàng thuoong mại, Kinh tế TP.HCM Publisher.

Vodová, P., (2011), "Liquidity of Czech Commercial Banks and Its Determinants", International Journal of Mathematical Models and Methods in Applied Sciences, vol. 5 (6), 2011, pp.1060-1067

Vodová, P. (2013a), Determinants of Commercial Banks' Liquidity in Hungary, Silesian University.

Vodová. P., (2013b), “Determinants of Commercial Banks' Liquidity in Poland”, in Proceedings of the $30^{\text {th }}$ International Conference Mathematical Methods in Economics. 